How to cite: Kubiak-Wójcicka, K (2020) Influence of Precipitation on Osa River Discharge in 1966-2015 Period. 2020 "Air and Water - Components of the Environment" Conference Proceedings, Cluj-Napoca, Romania, p. 1122, DOI: 10.24193/AWC2020_02.

\title{
INFLUENCE OF PRECIPITATION ON OSA RIVER DISCHARGE IN 1966-2015 PERIOD
}

\author{
Katarzyna KUBIAK-WÓJCICKA ${ }^{1}$
}

DOI: 10.24193/AWC2020_02

\begin{abstract}
The aim of the study was to determine the impact of precipitation on the volume of river discharge on a multiannual and seasonal basis. The research area covered the Osa River agricultural catchment located in northern Poland. For the purposes of the analysis, there were used the data from the Institute of Meteorology and Water Management - National Research Institute, covering average monthly sums of precipitation at the meteorological station in Radzyń Chełmiński and average monthly flows of the Osa River in the gauging station Rogóźno in 1966-2015. For the identification of dry and wet periods, the Standardized Precipitation Index (SPI) was used in various accumulation periods, i.e. 1, 3, 6, 9 and 12 months. In the years 1966-2015, the number of dry months (SPI $\leq-1.0)$ prevailed over wet months (SPI $\geq 1.0)$. Depending on the length of the precipitation accumulation period (1,3,6,9 or 12 months), there were identified between 89 and 138 dry months, which constituted from $14.8 \%$ to $23 \%$ of all months in the analyzed multi-year period, respectively. Wet months accounted for 81 $(13.5 \%)$ to $100(16.7 \%)$ months. Relationship between SPI values in different periods of accumulation and average discharge (SQ) of Osa River was presented in the form of a correlation coefficient $r$. The highest correlation coefficient between SPI and SQ was obtained between precipitation in accumulation period of 6 months and average monthly discharge $(\mathrm{r}=0.72)$. The indicators can be used for a drought early warning system, which is of particular importance for agricultural areas.
\end{abstract}

Keywords: precipitation, discharge, meteorological drought, SPI, River Osa, Poland

\section{INTRODUCTION}

Water deficit is a growing problem worldwide. Water scarcity affects many countries, even those located in temperate regions (Fleig et al., 2011). Drought is a complex phenomenon and hard to define. It is often the result of many complex factors interacting with each other. The onset of drought is usually associated with long-term lack or deficiency of precipitation and high air temperature (Kubiak-Wójcicka and Bąk, 2018). Precipitation deficiency leads to dry periods of varying severity. As a consequence of atmospheric drought, quantitative changes occur in the hydrological cycle.

The catchment response to precipitation deficiency is very variable and depends mainly on the physiographic characteristics of the catchment (permeability,

\footnotetext{
${ }^{1}$ Nicolaus Copernicus University, Faculty of Earth Sciences and Spatial Management, Lwowska 1, 87-100 Toruń, Poland, email: kubiak@umk.pl
} 
topography, land use and land cover), climatic conditions (precipitation and evapotranspiration) and human activity (López-Moreno et al., 2013; Haslinger et al., 2014). The complexity of the interaction among these factors can cause a discrepancy between the amount of precipitation and the amount of river runoff. Time lags between precipitation and other elements of the hydrological cycle are then observed (Lorenzo-Lacruz et al., 2013). Drought is a climate feature defined as a noticeable lack of water that causes damage to the environment and the economy (Spinoni et al., 2016; Diani et al., 2019). It is very important to study trends in river runoff because they represent the integration of climate variables and non-climatic factors in a specific area. Identifying future threats will allow adopting the best strategies for mitigating the effects of drought and creating an early warning system (Bachmair et al. 2015; Croitoru and Minea, 2018). Due to the complex impact of meteorological conditions on the volume of discharge in rivers, detailed analysis of each event is fundamental to a better understanding of this phenomenon.

The main purpose of the paper is to analyze the intensity and course of precipitation and their impact on the amount of average monthly discharge. This study aims to determine trends of precipitation and of discharge and to determine the correlation between precipitation changes and river runoff in the River Osa agricultural catchment area. The increased risk of meteorological drought results in a lower discharge in the river, which is extremely important for agricultural areas and the volume of plant production, as well as the possibility of irrigation of these areas.

\section{STUDY AREA AND METHODS}

The research area is the River Osa catchment, which is located in northern Poland. The total area is $1606.27 \mathrm{~km}^{2}$, and the length of the river is $109.84 \mathrm{~km}$ (Atlas podziału hydrograficznego Polski, 2005). The River Osa is the right tributary of the Vistula. The source of the river is located in the Iławskie Lakeland, the mouth of the river to the Vistula is located north of Grudziądz. The catchment has a diverse relief, characterized by a dense hydrographic network and many lakes. Currently, there are 12 lakes over 100 ha in the River Osa catchment area of which the largest are Karaś, Trupel, Goryńskie, Kucki and Wądzyńskie. The most important tributaries of the River Osa include the Lutryna and Gardęga rivers (Fig. 1). The catchment is built mainly of clays and sand bars. Arable lands dominate in terms of land use, which accounts for almost $70 \%$ of the catchment area. Forests cover $14.4 \%$ of the catchment, meadows around 10\% and swamps 1.78\% (Kubiak-Wójcicka, 2019a).

To determine the meteorological conditions in the years 1966-2015, average monthly precipitation sums obtained from 3 meteorological stations: Radzyń Chełmiński, Gardeja and Prabuty, were used. Discharge data of the River Osa in the Rogóźno gauging station were used for hydrological characterization. The gauging staion in Rogóźno closes the catchment area of $1135.11 \mathrm{~km}^{2}$, which constitutes $70.7 \%$ of the total catchment area (Atlas podziału hydrograficznego Polski, 2005). The location of the gauges is shown in Fig. 1. Meteorological and 
hydrological data from the period of 1966 to 2015 were obtained from the Institute of Meteorology and Water Management - National Research Institute.

A standardized precipitation index (SPI) was used to identify meteorological drought. SPI has been proposed by McKee et al. (1995), and makes it possible to determine dry and wet periods on the basis of precipitation sums in various time scales. It is widely used in the literature (Vicente-Serrano and López-Moreno, 2005; Łabędzki, 2007; Shukla and Wood, 2008; Zeleňáková et al., 2017), and also recommended by the WMO (World Meteorological Organization, 2012) for operational monitoring of drought risk (Barker et al. 2015; Kubiak-Wójcicka and Bąk, 2018).

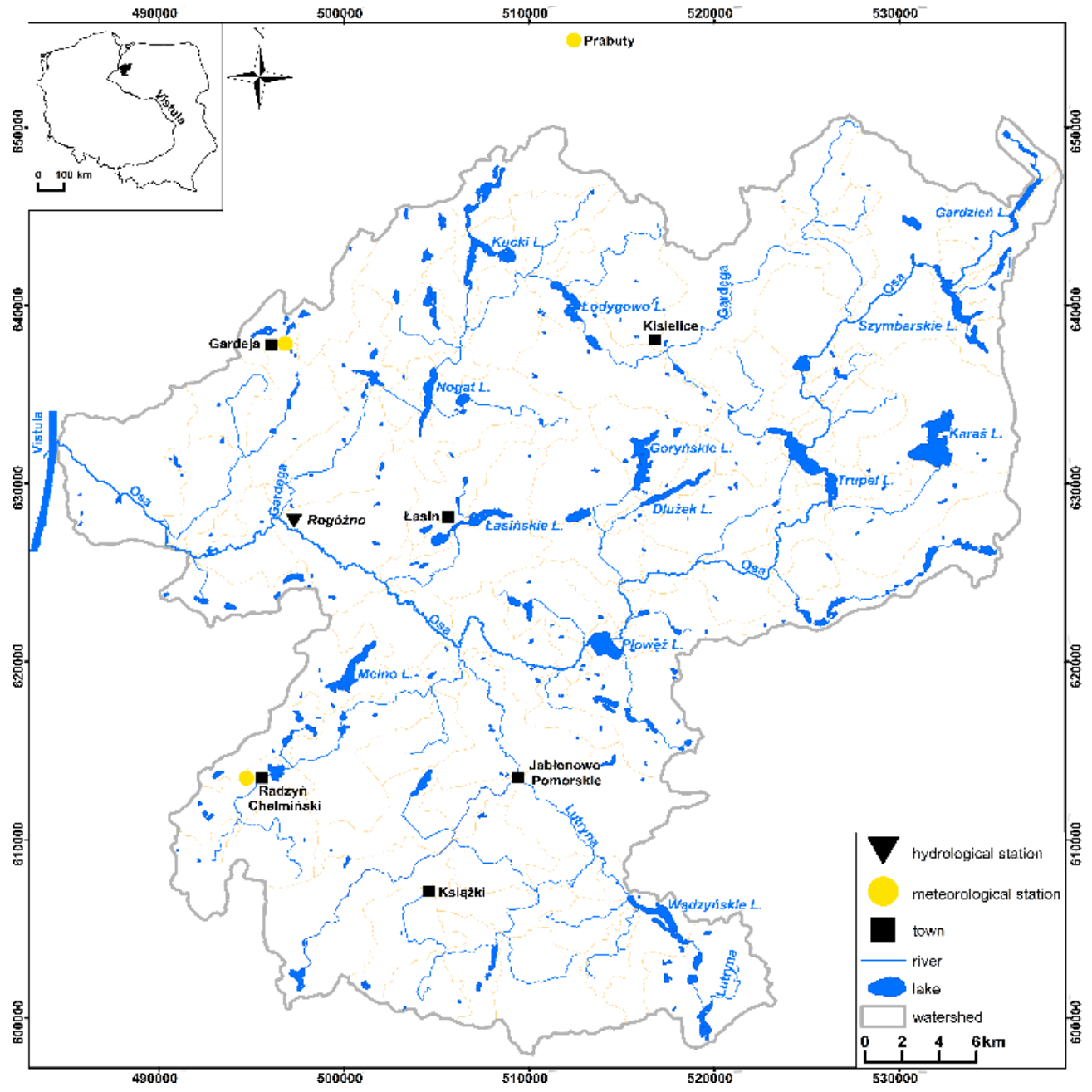

Fig. 1. River Osa catchment

SPI was calculated for precipitation data from the Radzyń Chelmiński meteorological station. This indicator defines a standardized deviation of the average monthly precipitation sums from the median value in the studied period. 
Precipitation sums were normalized by the transforming function $\mathrm{f}(\mathrm{P})=(\mathrm{P}) 1 / 3$ (Bąk and Kubiak-Wójcicka, 2016; 2017).

$\quad$ SPI $=$
where:
SPI - Standardized Precipitation Index
$\mathrm{f}(\mathrm{X})$ - transformed precipitation sum,
$\mu-$ mean of normalized index X
$\delta$ - standard deviation of index X

Depending on the obtained SPI values, the intensity of a given phenomenon can be classified. SPI values less than or equal to -1.0 indicate dry periods that reflect precipitation deficiency. SPI values greater than or equal to 1.0 characterize wet periods. The classification of drought intensity was carried out according to Table 1 .

Table 1. The classification scale for SPI values (McKee et al. 1993, Bąk and Kubiak-Wójcicka 2017)

\begin{tabular}{|l|l|}
\hline SPI value & Category \\
\hline $\mathrm{SPI} \geq 2.0$ & Extremely wet \\
\hline $2.0>\mathrm{SPI} \geq 1.5$ & Severely wet \\
\hline $1.5>\mathrm{SPI} \geq 1.0$ & Moderately wet \\
\hline $1.0>\mathrm{SPI}>-1.0$ & Normal \\
\hline$-1.0 \geq \mathrm{SPI}>-1.5$ & Moderately dry \\
\hline$-1.5 \geq \mathrm{SPI}>-2.0$ & Severely dry \\
\hline $\mathrm{SPI} \leq-2.0$ & Extremely dry \\
\hline
\end{tabular}

A prolonged (usually several months) period of small sums of precipitation or temporary lack of precipitation contributes to the formation of hydrological drought. The paper uses various sequences of accumulated precipitation sums, i.e. 1,3, 6, 9 and 12 months.

The relationship between meteorological drought and the discharge of River Osa was shown using the correlation coefficient $r$. The higher the correlation coefficient, the greater the impact of precipitation on the discharge is. According to the research of other authors, the existence of a significant correlation between these parameters occurs when $r>0.5$ (Kubiak-Wójcicka, 2019a).

\section{RESULTS AND DISCUSSIONS}

\subsection{Precipitation and discharge in period 1966-2015}

During the analyzed period of 1966-2015, the average sum of precipitation at the meteorological station in Radzyń Chełmiński was $565.5 \mathrm{~mm}$, in Gardeja 599.2 $\mathrm{mm}$ and in Prabuty 635.2 (Fig. 2). The obtained values are typical for the central lowland part of Poland, which belongs to the areas with the lowest precipitation totals in the country (less than $600 \mathrm{~mm}$ ) (Szwed, 2019). The linear trend of average annual atmospheric precipitation at the Gardeja meteorological station is clearly decreasing over the analyzed period. At the meteorological station in Prabuty, the linear trend is slightly decreasing, while in Radzyń Chelmiński precipitation does 
not show any change in the studied period, and the annual precipitation sums have been showing a stable trend. The highest annual precipitation was recorded in 1970 at the meteorological stations in Radzyń Chełmiński and Prabuty, respectively $814.3 \mathrm{~mm}$ and $1007.8 \mathrm{~mm}$, and in 1981 at the station Gardeja $(985.9 \mathrm{~mm})$. The lowest annual precipitation sums were observed in 1982 and 2000. These values, depending on the meteorological station, ranged from 368.8 to $410 \mathrm{~mm}$ (Table 2).

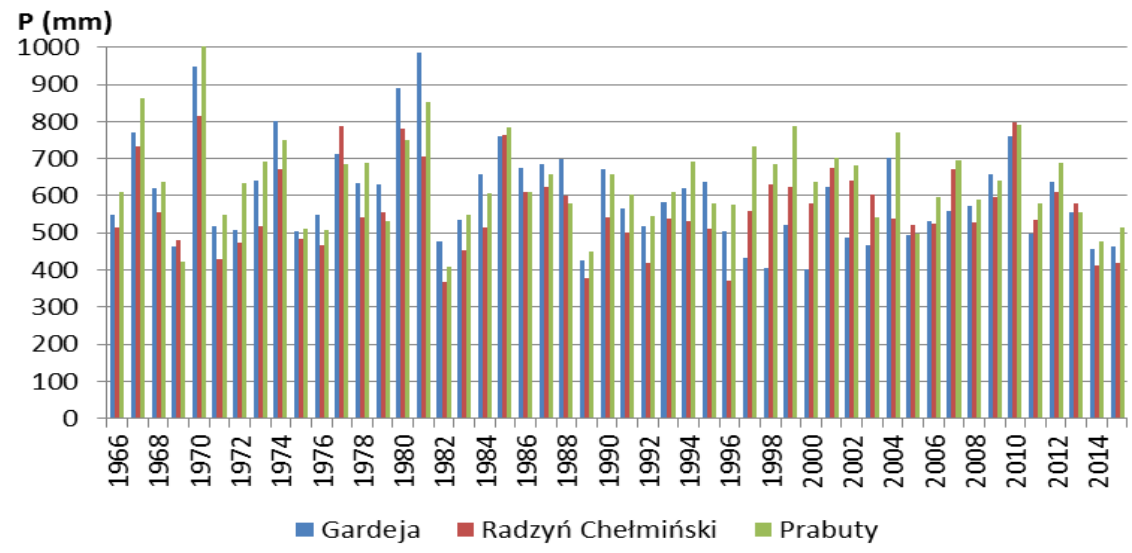

Fig. 2. Annual total precipitation at meteorological stations Radzyń Chelmiński, Gardeja and Prabuty in the years 1966-2015

The average long-term discharge of the Osa River recorded at the Rogóźno gauging station was $4.40 \mathrm{~m}^{3} \mathrm{~s}^{-1}$, which results in specific discharge of $3.9 \mathrm{dm}^{3} \mathrm{~s}^{-1} \mathrm{~km}^{-}$ 2. Specific discharge from the River Osa catchment is one of the lowest in the area of Poland. The average specific discharge from the entire Vistula River basin was $5.39 \mathrm{dm}^{3} \mathrm{~s}^{-1} \mathrm{~km}^{-2}$ in the period 1951-2015 (Kubiak-Wójcicka, 2019b).

Table 2. Average, maximum and minimum annual precipitation at meteorological stations in the period 1966-2015

\begin{tabular}{|c|c|c|c|c|}
\hline $\begin{array}{l}\text { Meteorological } \\
\text { station name }\end{array}$ & $\begin{array}{c}\text { Maximum annual } \\
\text { precipitation sum in mm } \\
\text { (year of the occurrence) }\end{array}$ & $\begin{array}{c}\text { Minimum annual } \\
\text { precipitation sum in mm } \\
\text { (year of the occurrence) }\end{array}$ & $\begin{array}{l}\text { Average annual } \\
\text { precipitation sum } \\
\text { in } \mathrm{mm} \text { (I-XII) }\end{array}$ & $\begin{array}{c}\text { Linear trend of average } \\
\text { annual precipitation } \\
\text { sums }\end{array}$ \\
\hline Gardeja & $985.9(1981)$ & $402.0(2000)$ & 599.2 & $\begin{array}{c}y=-2.9475 x+674.37 \\
R^{2}=0.1042\end{array}$ \\
\hline $\begin{array}{c}\text { Radzyń } \\
\text { Chełmiński }\end{array}$ & 814.3 (1970) & 368.8 (1982) & 565.5 & $\begin{array}{c}y=-0.4135 x+576.06 \\
R^{2}=0.0029\end{array}$ \\
\hline Prabuty & 1007.8 (1970) & 410.0 (1982) & 635.2 & $\begin{array}{c}y=-0.9958 x+660.62 \\
R^{2}=0.0152\end{array}$ \\
\hline
\end{tabular}

The River Osa specific discharge was also lower compared to other Pomeranian rivers, e.g. Drawa (Kubiak-Wójcicka, 2019c) or Gwda (Kubiak-Wójcicka et al., 2019). The highest annual discharge was recorded in 1980 and it was twice as high as the average value of the analyzed period $\left(39.3 \mathrm{~m}^{3} \mathrm{~s}^{-1}\right)$. The lowest discharge occurred in 2015 and it was $1.36 \mathrm{~m}^{3} \mathrm{~s}^{-1} .2015$ was one of the driest years in terms of precipitation and temperature anomalies in Central Europe over the past 15 
years (Laaha et al., 2017; Fendeková et al., 2018; Hänsel et al., 2019), including Poland. Small sums of precipitation (about $420 \mathrm{~mm}$ ) recorded in 2014 and 2015 at the meteorological station in Radzyń Chełmiński contributed to the formation of hydrological drought in 2015. In 2015, in central Poland, small watercourses, which are fed with shallow circulation water, dried up (Solarczyk, KubiakWójcicka, 2019). Throughout the period 1966-2015 there is a clear downward trend in maximum, average and minimum discharges (Fig. 3).

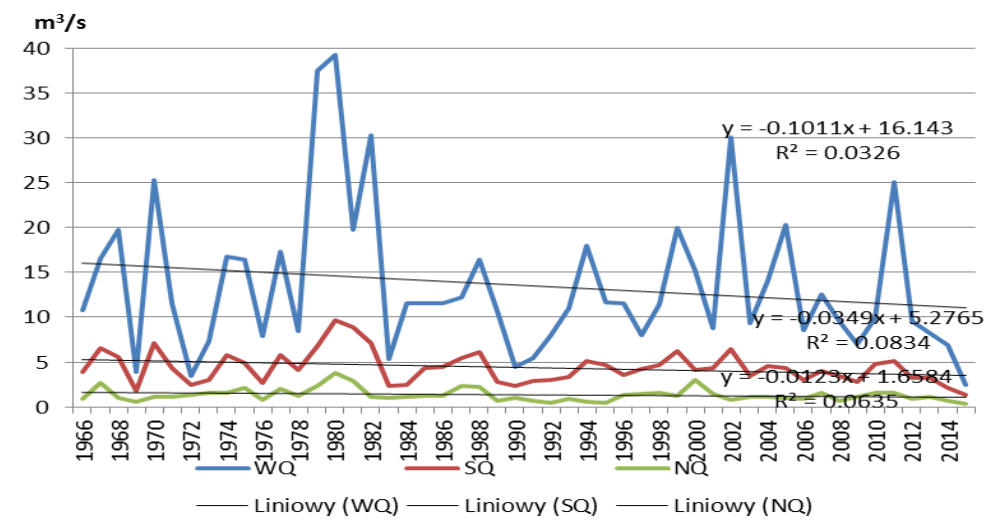

Fig. 3. Maximum (WQ), minimum (NQ) and average annual discharges of River Osa at gauging station Rogóźno in the period 1966-2015

Analysis of precipitation and discharge in the analyzed multi-year period 19662015 showed uneven distribution throughout the year. In the cool half-year (October-March), precipitation accounts for $37.4 \%$ of precipitation during the year, while in the warm half-year $-62.6 \%$. Occasionally there occur years in which precipitation in the cold half-year prevails (2004 - 52.3\%, $1994-51.2 \%, 1989$ $50.3 \%)$. The highest precipitation amplitudes among particular months of a year occurred in June and July and the lowest in February (Fig. 4).

a)

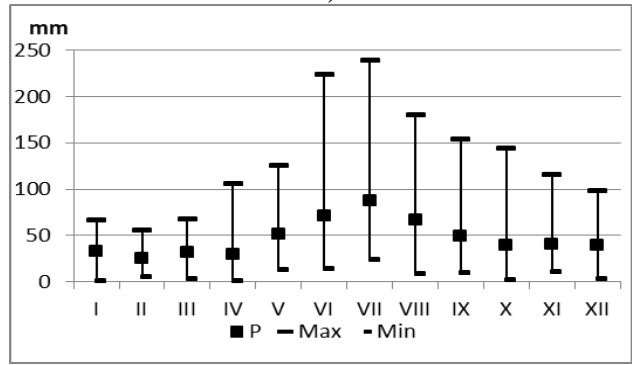

b)

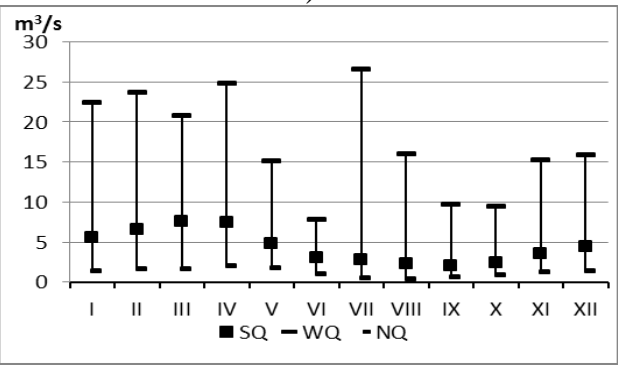

Fig. 4. Maximum, average and minimum monthly precipitation at meteorological station Radzyń Chelmiński (a) and River Osa discharges at gauging station Rogóźno (b) in the period 1966-2015

The annual distribution is dominated by the outflow in the cool half-year (X-III) $-57.2 \%$ over the outflow in the summer (IV-IX), which accounted for $42.8 \%$ of 
the outflow during the year. Exceptions occurred in 9 years, in which the outflow in the warm half-year (IV-IX) was higher than in the cool half-year $(1969,1970$, 1977, 1979, 1980, 1985, 1986, 1996, 1997).

\subsection{Relationship between meteorological drought (SPI) and discharges in seasonal terms}

The identification of dry and wet periods was based on data from the meteorological station in Radzyń Chełmiński due to its location - within the catchment, above the water gauge station on the Osa River in Rogóźno. Dry and wet periods were determined based on the SPI index.

Depending on the accumulation period in the years 1966-2015, there were identified from 89 (for SPI-1) to 131 (for SPI-3) dry months (SPI values are lower than or equal to -1.0). The number of wet months (SPI $\geq 1.0)$ in the analyzed period was lower than the dry months and ranged from 81 (for SPI-3) to 100 (for SPI-12). The lowest SPI value was -3.17 and was recorded in January 1997 for a 1 month accumulation period. As the accumulation period increased, the minimum SPI value increased and in the 12-month period was -2.33, which was recorded in May 2015. The maximum SPI value decreased with the length of the SPI accumulation period and was 2.56 for SPI-9 and SPI-12 (Table 3).

Table 3. Values of the SPI

\begin{tabular}{|l|l|l|l|l|}
\hline SPI & $\begin{array}{l}\text { Number of months } \\
\text { with SPI } \leq-1.0\end{array}$ & $\begin{array}{l}\text { Number of wet } \\
\text { months SPI } \geq \mathbf{1 . 0}\end{array}$ & $\begin{array}{l}\text { Maximum SPI value } \\
\text { (occurrence date) }\end{array}$ & $\begin{array}{l}\text { Minimum SPI value } \\
\text { (occurrence date) }\end{array}$ \\
\hline SPI-1 & 89 & 89 & 2.92 (XI 1970) & -3.16 (I 1997) \\
\hline SPI-3 & 138 & 81 & 2.85 (VIII 1980) & -3.07 (I 1997) \\
\hline SPI-6 & 101 & 97 & 2.63 (XI 1980) & -2.96 (XII 1982) \\
\hline SPI-9 & 99 & 95 & 2.56 (II 1981) & -2.85 (VI 1996) \\
\hline SPI-12 & 97 & 100 & 2.56 (VIII 1977) & -2.33 (V 2015) \\
\hline
\end{tabular}

In total, 381 to 422 regular months were identified, which is $63.5 \%$ to $70.3 \%$ of months in the analyzed multi-year period (Table 4). The number of dry months $(\mathrm{SPI} \leq-1.0)$ accounted for from $14.8 \%$ to $23 \%$, while the wet months (SPI $\geq 1.0)$ from $13.5 \%$ to $16.7 \%$ of all months (Table 4 ).

Table 4. The share (\%) of dry and wet periods at meteorological station in Radzyń Chetmiński in years 1966-2015.

\begin{tabular}{|l|r|r|r|r|r|r|r|}
\hline & SPI $\geq \mathbf{2 . 0}$ & $\mathbf{2 . 0}>$ SPI $\geq \mathbf{1 . 5}$ & $\mathbf{1 . 5}>$ SPI $\geq \mathbf{1 . 0}$ & $\mathbf{1 . 0}>$ SPI $>\mathbf{- 1 . 0}$ & $\mathbf{- 1 . 0} \geq$ SPI $>\mathbf{- 1 . 5}$ & $\mathbf{- 1 . 5} \geq$ SPI $<-2.0$ & SPI $\leq-\mathbf{2 . 0}$ \\
\hline SPI-1 & 2.67 & 3.00 & 9.17 & 70.33 & 8.66 & 3.50 & 2.67 \\
\hline SPI-3 & 2.50 & 2.17 & 8.83 & 63.50 & 16.66 & 3.67 & 2.67 \\
\hline SPI-6 & 2.50 & 4.00 & 9.67 & 67.00 & 10.50 & 3.83 & 2.50 \\
\hline SPI-9 & 2.50 & 4.00 & 9.33 & 67.67 & 9.00 & 5.67 & 1.83 \\
\hline SPI-12 & 2.00 & 4.83 & 9.83 & 67.17 & 7.50 & 7.17 & 1.50 \\
\hline
\end{tabular}

Taking into account the detailed breakdown into period intensity classes, according to Table 1 , extremely humid months (SPI $\geq 2.0$ ) accounted for $2.00 \%$ to $2.67 \%$, while extremely dry months (SPI $\leq-2.0)$ from $1.50 \%$ to $2.67 \%$ of all months. Periods with moderately dry months $(7.5-16.66 \%)$ and moderately wet months $(8.83 \%-9.67 \%)$ are more diverse. During the analyzed years, dry months prevail over wet months. 
The obtained number of dry months is lower than the number of months with meteorological drought. It is assumed that meteorological drought occurs when the SPI value is negative and at least one value of the adopted indicator is less than or equal to -1.0. Thus, any negative value preceding an SPI value greater than or equal to -1.0 is already included in the drought. Interruption of drought occurs when $X \geq 0.0$. This means that the onset of meteorological drought occurs when the SPI value is negative before it reaches a value greater than or equal to -1.0. In the Osa basin, the number of all months with meteorological drought ranged from 197 months (SPI-1) to 247 months for SPI-12 (Kubiak-Wójcicka, 2019a).

The relation between precipitation in the form of SPI index in various periods of accumulation and average monthly discharges is presented in Fig. 5.

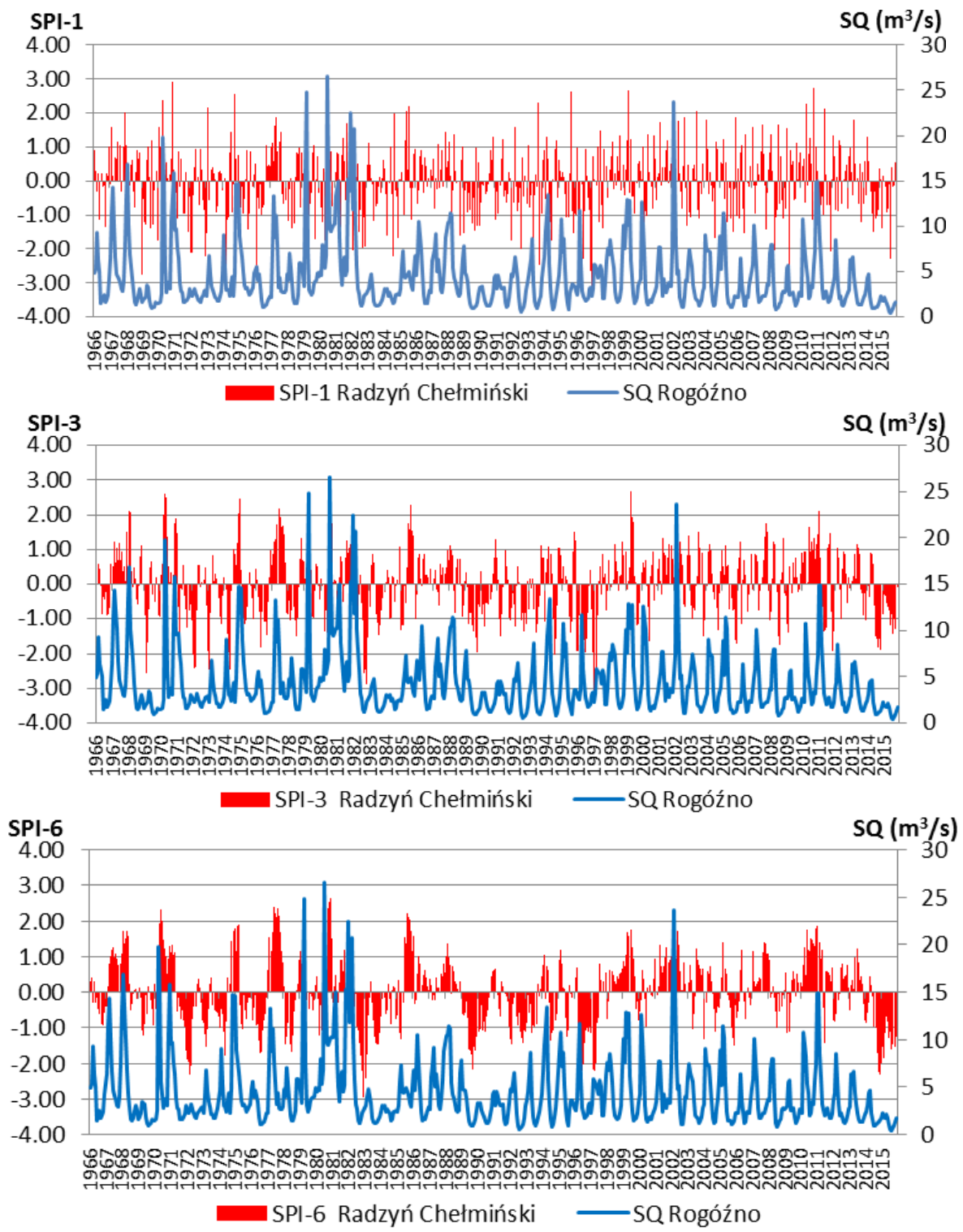




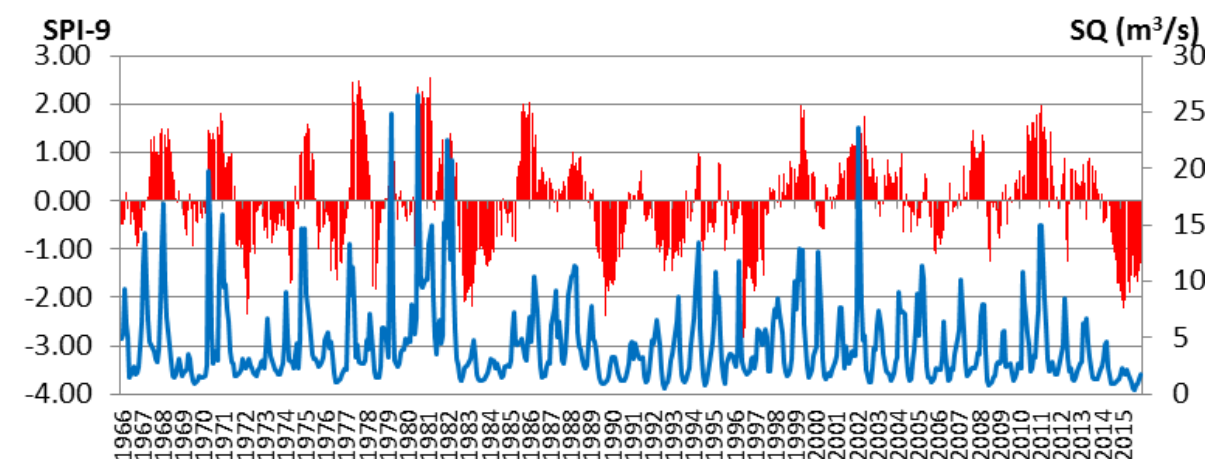

SPI-9 Radzyń Chełmiński —SQ Rogóźno

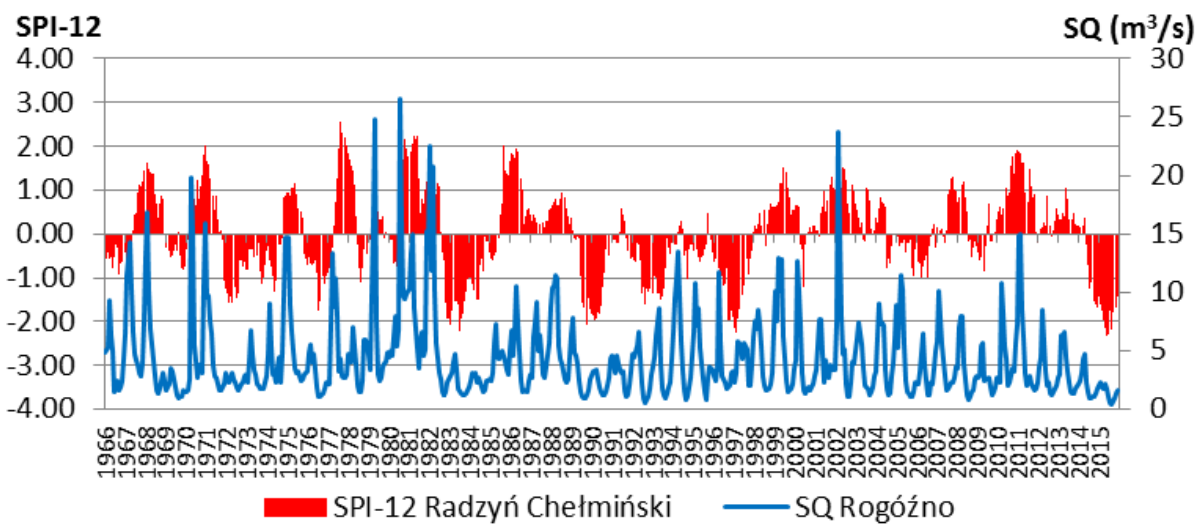

Fig. 5. The SPI index in various time scales against the average monthly flows in the years 1966-2015

The relationship between precipitation and average monthly discharge was presented in the form of a correlation coefficient $r$. The lowest correlation coefficients $r$ was obtained in a 1-month precipitation accumulation period and it took place in August $(r=0.12)$ and September $(r=0.11)$. A weak relation may result from high air temperature and supplying the river with water accumulated in previous months.

Table 5. Correlation coefficient between SPI values and average monthly discharges of River Osa in 1966-2015

\begin{tabular}{|l|l|l|l|l|l|l|l|l|l|l|l|l|}
\hline & I & II & III & IV & V & VI & VII & VIII & IX & X & XI & XII \\
\hline SPI-1 vs SQ & 0.14 & 0.16 & 0.31 & 0.29 & 0.23 & $\mathbf{0 . 5 4}$ & 0.46 & 0.12 & 0.11 & 0.27 & 0.36 & 0.28 \\
SPI-3 vs SQ & 0.49 & 0.50 & 0.46 & 0.51 & 0.60 & $\mathbf{0 . 7 1}$ & 0.56 & 0.69 & 0.58 & 0.45 & 0.53 & 0.63 \\
SPI-6 vs SQ & 0.55 & 0.58 & 0.60 & 0.46 & 0.63 & $\mathbf{0 . 7 2}$ & 0.55 & 0.61 & 0.64 & 0.61 & 0.60 & 0.62 \\
SPI-9 vs SQ & 0.61 & 0.59 & $\mathbf{0 . 6 4}$ & 0.59 & 0.59 & 0.63 & 0.49 & 0.57 & 0.60 & 0.58 & 0.53 & 0.61 \\
SPI-12 vs SQ & $\mathbf{0 . 6 2}$ & 0.61 & 0.55 & 0.35 & 0.44 & 0.58 & 0.48 & 0.53 & 0.56 & 0.54 & 0.51 & 0.61 \\
\hline
\end{tabular}

The correlation coefficients between SPI and SQ were the highest for the 6month accumulation period and occurred in June (0.72) (table 3). The largest correlations between precipitation and discharge were noted in the cool half- 
year $(\mathrm{X}$-III) during the 9-month period $(\mathrm{r}=0.51)$ and 6 - and 12 -month periods $(\mathrm{r}=0.50)$. It is assumed that when $\mathrm{r}$ values are higher than 0.5 in all months, it proves a high degree of dependence (Bachmair et al. 2015). In the warm halfyear (IV-IX) the highest values of the $r$ coefficient were recorded in the 3month period $(\mathrm{r}=0.46)$.

The obtained results confirm the conclusions of other authors who signaled the lack of a linear relationship between meteorological drought and average discharge, because usually the river's response to precipitation is delayed in time (Bloomfield and Marchant, 2013; Huang et al. 2017). An additional factor affecting the complex relationship between precipitation and discharges is irrigation in agricultural areas carried out during the summer.

\section{CONCLUSIONS}

The paper presents the impact of atmospheric precipitation on the discharge of the Osa River in 1966-2015. The observed changes in discharge in the river were associated with the course and distribution of precipitation and its magnitude in individual years.

- the annual sum of precipitation in the years 1966-2015 at the meteorological station in Radzyń Chełmiński shows no trend, while at the Gardeja and Prabuty stations the precipitation shows a downward trend,

- annual averages, as well as maximum and minimum discharges of River Osa at the gauging station in Rogóźno show a clear downward trend over the years 1966-2015

- in the studied period of 1966-2015, the number of dry months $(\mathrm{SPI} \leq-1.0)$ prevailed over wet months (SPI $\geq 1.0)$. Depending on the length of the precipitation accumulation period (1, 3, 6, 9 or 12 months), 89 (14.8\%) to 138 dry months (23\%) were identified, which constituted from $14.8 \%$ to $23 \%$ of all months in the analyzed multi-year period. Wet months accounted for 81 (13.5\%) to 100 months (16.7\%)

- in the analyzed period there prevailed normal months, for which the SPI values in various time scales were in the range $\leq 1.0$ and $\geq-1.0$. In total, 381 to 422 normal months were identified, which constituted from $63.5 \%$ to $70.3 \%$ of months in the analyzed multi-year period (Table 4).

- the relationship between SPI values in different periods of accumulation and the average discharge of River Osa is presented in the form of a correlation coefficient $r$. The highest correlation coefficient between SPI and SQ was obtained in the accumulation period of 6 months $(r=0.72)$.

- the largest correlations between precipitation and discharge were noted in the cool half-year (X-III) in periods of 6, 9 and 12 months, the $\mathrm{r}$ factor was 0.50 and 0.51 , respectively.

- the relationship between the SPI indicator and SQ can be used for monitoring and early warning against drought, which is crucial for agriculture, especially during the growing season. 


\section{REFERENCES}

1. Atlas podziału hydrograficznego Polski. (2005), IMGW, Warszawa.

2. Bachmair S., Svensson C., Hannaford J., Barker L. J., Stahl K. (2015), A quantitative analysis to objectively appraise drought indicators and model drought impacts. Hydrol. Earth Syst. Sci. Discuss., 12, 9437-9488. DOI:10.5194/hessd-12-9437-2015

3. Barker L.J., Hannaford J., Chiverton A., Svensson C. (2015), From meteorological to hydrological drought using the standardized indicators. Hydrol. Earth Syst. Sci. Discuss., 12, 12827-12875. DOI:10.5194/hessd-12-12827-2015

4. Bąk, B., Kubiak-Wójcicka, K. (2016), Assessment of meteorological and hydrological drought in Torun (central Poland town) in 1971-2010 based on standardized indicators. In P. Gastescu \& P. Bretcan (Eds.), 3rd International Conference Water resources and wetlands Conference proceedings. (pp. 164-170). Tulcea: Romania.

5. Bąk, B., Kubiak-Wójcicka, K. (2017), Impact of meteorological drought on hydrological drought in Torun (central Poland) in the period of 1971-2015. Journal of Water and Land Development, 32(I-III), 3-12. DOI: https://doi.org/10.1515/jwld-2017-0001

6. Bloomfield J.P., Marchant B. P. (2013), Analysis of groundwater drought building on the standardised precipitation index approach. Hydrol. Earth Syst. Sci., 17, 4769-4787. DOI:10.5194/hess-17-4769-2013

7. Croitoru A-E., Minea I. (2014), The impact of climate changes on rivers discharge in Eastern Romania. Theor Appl Climatol, DOI: 10.1007/s00704-014-1194-z

8. Diani K., Kacimi I., Zemzami M., Tabyaoui H., Haghighi A. T. (2019), Evaluation of meteorological drought using the Standardized Precipitation Index (SPI) in the High Ziz River basin, Morocco. Limnol. Rev., 19, 3, 125-135. DOI 10.2478/limre-2019-0011

9. Fendeková M., Gauster T., Labudová L., Vrablíková D., Danáčová Z, Fendek M., Pekárová P. (2018), Analysing 21st century meteorological and hydrological drought events in Slovakia. J. Hydrol. Hydromech., 66, 4, 393-403. DOI: 10.2478/johh-2018-0026

10. Fleig A. K., Tallaksen L. M., Hisdal H., Hannah D. H. (2011), Regional hydrological drought in north-western Europe: linking a new Regional Drought Area Index with weather types. Hydrological Processes, 25, 1163-1179. DOI: 10.1002/hyp.7644

11. Haslinger K., Koffler D., Schöner W., Laaha G. (2014), Exploring the link between meteorological drought and streamflow: Effects of climate-catchment interaction. Water Resources Research, 50, 2468-2487. doi:10.1002/2013WR015051.

12. Hänsel S., Ustrnul Z., Łupikasza E., Skalak P. (2019), Assessing seasonal drought variations and trends over Central Europe. Advances in Water Resources, 127, 53 75. https://doi.org/10.1016/j.advwatres.2019.03.005

13. Huang S., Li P., Huang Q., Leng G., Hou B., Ma L. (2017), The propagation from meteorological to hydrological drought and its potential influence factors. Journal of Hydrology, 547, 184-195.DOI: http://dx.doi.org/10.1016/j.jhydrol.2017.01.041

14. Kubiak-Wójcicka K., Bąk B. (2018), Monitoring of meteorological and hydrological droughts in the Vistula basin (Poland). Environ Monit Assess, 190, 11, 1-16. DOI: 10.1007/s10661-018-7058-8.

15. Kubiak-Wójcicka K. (2019a), Dynamics of meteorological and hydrological droughts in the agricultural catchments. Research for Rural Development, Water Management, 2019, vol. 1, 111-117. DOI: 10.22616/rrd.25.2019.017 
16. Kubiak-Wójcicka K. (2019b), Long-term variability of runoff of Vistula River in 1951-2015. "Air and Water - Components of the Environment" Conference Proceedings, Cluj-Napoca, Romania, pp. 109-120. DOI: 10.24193/AWC2019_11

17. Kubiak-Wójcicka K. (2019c), The course of hydrological drought in the River Drawa catchment (Northern Poland) as characterized by the Standardized Runoff Index. AIP Conference Proceedings, 2186, 12000. https://doi.org/10.1063/1.5138035

18. Kubiak-Wójcicka K., Zelenakova M., Purcz P., Simovova D. (2019), The use of a Standardized Runoff Indicator for hydrological characterization of selected rivers of Poland and Slovakia. Middle Pomeranian Scientific Society of the Environment Protection, 21, 167-183. http://ros.edu.pl/images/roczniki/2019/010_ROS_V21_R2019.pdf

19. Laaha G., Gauster T., Tallaksen L.M., Vidal J-P, Stahl K., Prudhomme Ch., Heudorfer B., Vlnas R., Ionita M, Van Lanen H.A.J., Adler M-J, Caillouet L, Delus C, Fendekova M., Gailliez S., Hannaford J., Kingston D., Van Loon A.F, Mediero L, Osuch M., Romanowicz R., Sauquet E, Stagge J.H., \& Wong H.W. (2017), The European 2015 drought from a hydrological perspective. Hydrol. Earth Syst. Sci., 21, 3001-3024. https://doi.org/10.5194/hess-21-3001-2017

20. Lorenzo-Lacruz J., Vicente-Serrano S. M., González-Hidalgo J. C., LópezMoreno J. I., Cortesi N. (2013), Hydrological drought response to meteorological drought in the Iberian Peninsula. Clim. Res., 58, 117-131.

21. López-Moreno J. I., Vicente-Serrano S. M., Zabalza J., Beguería S., Lorenzo-Lacruz J., Azorin-Molina C., Morán-Tejeda E. (2013), Hydrological response to climate variability at different time scales: A study in the Ebro basin. J. Hydrol., 477,175-188.

22. Łabędzki L. (2007), Estimation of local drought frequency in central Poland using Standardized Precipitation Index SPI. Irrigation and Drainage, 56, 67-77. DOI: 10.1002/ird.285.

23. McKee, T.B., Doesken, N.J., \& Kleist, J. (1995), Drought monitoring with multiple time scales. Preprints of the 9th Conference of Applied Climatology, 1520 January 1995, Dallas, pp. 233-236.

24. Shukla, S., Wood W. (2008), Use of a standardised runoff index for characterizing hydrologic drought. Geophysical Research Letters, 35, L02405. DOI:10.1029/2007GL032487.

25. Solarczyk A., Kubiak-Wójcicka K. (2019), The exhaustion of water resources in the Kuyavian-Pomeranian voivodship in drought condition in 2015. Research for Rural Development, Water Management, 1, 118-125. DOI: 10.22616/rrd.25.2019.018.

26. Spinoni J., Naumann G., Vogt J.J., Barbosa B. (2015). The biggest drought events in Europe from 1950 to 2012. Journal of Hydrology, 3, 509-524. http://dx.doi.org/10.1016/j.ejrh.2015.01.001

27. Szwed M. (2018), Variability of precipitation in Poland under climate change. Theoretical and Applied Climatology. DOI: https://doi.org/10.1007/s00704-018-2408-6.

28. Vicente-Serrano, S.M. \& López-Moreno, J.I. (2005), Hydrological response to different time scales of climatological drought: an evaluation of the Standardized Precipitation Index in a mountainous Mediterranean basin. Hydrol. Earth Syst. Sci., 9, 523-533. DOI:10.5194/hess-9-523-2005.

29. WMO (2012), Standardized precipitation index user guide. M. Svoboda, M. Hayes, and D. Wood, Eds. (WMO-No. 1090). Geneva, Switzerland: WMO.

30. Zeleňáková M., Vido J., Portela M. M., Purcz P., Blištán P., Hlavatá H., Hluštík P. (2017), Precipitation trends over Slovakia in the period 1981-2013. Water, 9, 922. DOI:10.3390/w9120922 